\title{
A rare case of intraosseous ganglion of the triquetrum
}

\author{
Kemik içi triquetrum ganglionu: Nadir bir olgu \\ Boris Matev, Georgi P. Georgiev, Luben Stokov \\ University Hospital of Orthopaedics "Prof. B. Boychev", Medical University Sofia, Bulgaria
}

\begin{abstract}
Carpal intraosseous ganglia are one of the rarely seen pathologic conditions in the hand. In this report we present a rare case of an intraosseous ganglion cyst in a 16-year-old girl located in the triquetrum bone as an uncommon cause of wrist pain. Radiographic and magnetic resonance imaging demonstrated the cystic lesion into the triquetrum. The patient was successfully treated by excision of the ganglion cyst and curettage of the bone. Clinical aspects, radiological findings and treatment modalities of this condition were briefly reviewed. J Clin Exp Invest 2012; 3(1): 111-112
\end{abstract}

Key words: Intraosseous ganglion, triquetrum, wrist

\section{INTRODUCTION}

Intraosseous ganglion (IOG) of the carpal bones is infrequent, benign nonneoplastic bone lesion that occurs predominantly in young and middle-aged adults. ${ }^{1-4}$ Isolated cases of this pathological condition have been reported, most commonly in the lunate and scaphoid, followed by the capitate, triquetrum and trapezoid bones. ${ }^{1-4}$ It usually presents with chronic wrist pain with evident radiological lucency in carpal bones. ${ }^{1-3}$ Differential diagnosis of this lytic lesion includes unicameral bone cyst, degenerative cyst, fibrous developmental defect, osteomyelitis, juxta-articular cysts of osteoarthritis and post-traumatic cyst. ${ }^{1,5}$

\section{CASE}

Herein, we present a rare case of a symptomatic IOG of the triquetrum bone in a 16-year-old girl on the right wrist, which was successfully treated by intralesional curettage. The girl was brought to our department with 6-months history of activity related pain and pain under pressure in her right wrist. She had no history of trauma and inflammatory disease. Physical examination revealed limitation in range

\section{ÖZET}

Karpal kemik içi ganglionlar elde nadir rastlanan patolojik durumlardır. Bu raporda biz 16 yaşındaki kız hastada alışıımamış bir bilek ağrısı nedeni olan triquetrum kemiğinde yerleşmiş bir kemik içi ganglionunu sunuyoruz. Radyografik ve magnetik rezonans görüntüleme triquetrumda kisitk bir lezyonu gösterdi. Hasta ganglion kistinin eksizyonu ve kemik küretajı ile başarıı bir şekilde tedavi edildi. Klinik yönleri, radyolojik bulgular ve tedavi seçenekleri kısaca gözden geçirildi.

Anahtar kelimeler: Kemik içi ganglion, triquetrum, bilek

motion in both extension and flexion (flexion: $45^{\circ}$; extension: $60^{\circ}$ ) when compared to the left (flexion: $85^{\circ}$; extension: $90^{\circ}$ ). Pinch and grip strengths in the affected hand were diminished. Laboratory tests were in normal limits. X-ray revealed a radiolucent lesion within the triquetrum with a slightly sclerotic margins (Fig. 1a, b). Magnetic resonance imaging (MRI) confirmed the lesion and the presence of a fluid (Fig. 1c). Surgical treatment was performed through a dorsal approach. A fluid-filled soft tissue mass communicating to the triquetrum wall was detected. Excision of the ganglion cyst and curettage of the affected bone was performed. We also observed signs of aseptic inflammation with thickened synovial membrane. Afterward, the capsule-ligament apparatus was repaired. A short arm plaster cast was applied for three weeks. The postoperative period was uneventful. Histological finding were characteristic for an IOG and present a thin walled cyst surrounded by flattened, synovial-like fibroconnective cells with no true epithelial line. Physical therapy was started after 21 days of immobilization. The range of motion had greatly improved and the girl was totally free from earlier symptoms and had full grip strength three months after operation. 

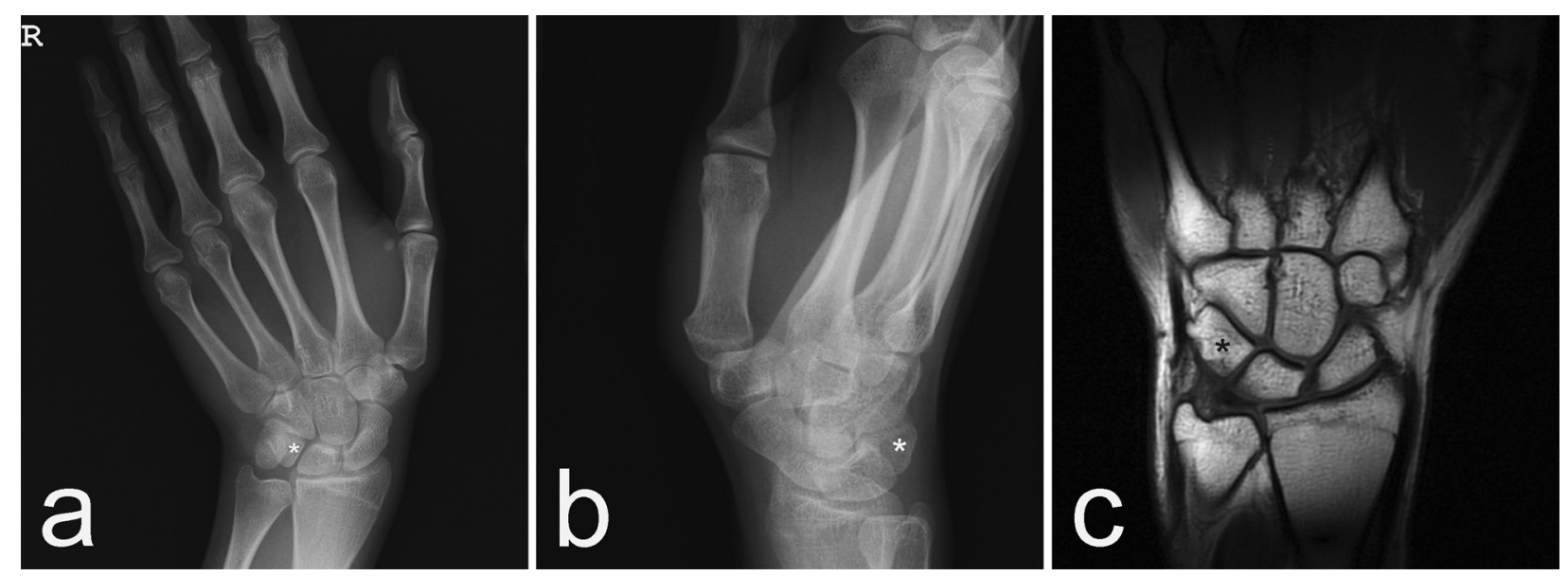

Fig. 1a. Antero-posterior radiograph of the right hand shows a radiolucent lesion within the triquetrum with slightly sclerotic margins (asterisk).

Fig. 1b. Lateral radiograph shows a radiolucent lesion within the triquetrum with slightly sclerotic margins (asterisk).

Fig. 1c. Magnetic resonance imaging scans of the right hand confirmed the lesion within the triquetrum (asterisk).

\section{DISCUSSION}

Intraosseous ganglion of the carpal bones is an uncommon cause of chronic wrist pain. ${ }^{1}$ The pathogenesis of this condition remains unclear. ${ }^{1,2}$ In the current literature different theories as synovial herniation, neoplasia, metaplasia of mesenchymal precursor cells, proliferation of synovial rest cells and traumatic mucoid degeneration of connective tissue have been proposed.1,2 Pathologically IOG is identical to its soft tissue counterpart, with a thin translucent wall composed of collagen fibres devoid of synovial lining and contains viscous clear fluid that has a high concentration of hyaluronic acid4. There are two types of IOG: the first type, which is more common, developed within the bone; the second type presented a soft tissue ganglion connected to joint tissues with secondary penetration into bone. ${ }^{2}$ Usually, IOG is eccentrically localized in the periphery of the bone with radiologically observed radiolucent well-defined osteolytic area outlined by a sclerotic rim penetrating or not to the adjacent joint. ${ }^{1-3}$ Other imaging techniques as computed tomography and MRI could be useful to clarify the extent of the abnormality and aid in surgical planning. ${ }^{2}$ Moreover, MRI can reveal an intra-articular extension in relation to the defect on the surface of the bone. ${ }^{1}$ The operative treatment of the IOG in most cases includes curettage of the cyst and packing with cancellous bone graft if the cavity is large..$^{2-4}$ This surgical treatment have some complications as painful scar, infection, haematoma, fracture, and gait disturbances. ${ }^{2}$ Chen et al. 2 proposed to intrale- sional curettage and autogenous bone marrow graft to be added an autogenous fibrin clot graft. They considered that the fibrin clot had a large amount of aggregated platelets, which contained platelet-derived growth factor (PDGF) and transforming growth factor beta (TGF- $\beta$ ). These factors stimulated cells growth in new callus and advanced fracture healing. Arthroscopically assisted minimally invasive technique of debridement and grafting of the IOG with the aim of reducing the morbidity seen with open techniques have also been reported. ${ }^{1}$ In cases of cortical perforation the calcium phosphate bone cement is a useful material for repairing bone defect after curettage. ${ }^{3}$ Overall, the recurrence rate after any treatment is very low. ${ }^{2-4}$

\section{REFERENCES}

1. Bain GI, Turner PC, Ashwood N. Arthroscopically assisted treatment of intraosseous ganglions of the lunate. Tech Hand Up Extrem Surg 2008;12(4):202-7.

2. Chen YC, Wang SJ, Shen PH, Huang GS, Lee HS, Wu SS. Intraosseous ganglion cyst of the capitate treated by intralesional curettage, autogenous bone marrow graft and autogenous fibrin clot graft. J Chin Med Assoc 2007;70(5):222-6.

3. Kural C, Sungur I, Cetinus E. Bilateral lunate intraosseous ganglia. Orthopedics 2010; 33(7):514.

4. Tuzuner T, Subasi M, Alper M, Kara H, Orhan Z. Penetrating type intraosseous ganglion cyst of the lunate bone. West Indian Med J 2005; 54(6):384-6.

5. Mogan JV, Newberg AH, Davis PH. Intraosseous ganglion of the lunate. J Hand Surg Am 1981;6(1):61-3. 